\title{
Assessment of the Impact of Experience Marketing Dimensions on City Loyalty
}

\begin{abstract}
The article aims to identify the importance of experience marketing dimensions for city residents' and visitors' loyalty. The theoretical part of this article analyses the concepts of experience and city marketing, city customers and their importance to the city, and distinguishes the main dimensions of experience marketing in the city. During the quantitative research, the impact of experience marketing dimensions on the loyalty of Kaunas city residents and visitors was determined. Also, using regression analysis the relation between the evaluation of experience marketing dimensions of Kaunas city residents and visitors and the behavioural and attitudinal loyalty was established.
\end{abstract}

Keywords: city loyalty, city marketing, experience marketing.

Straipsnyje siekiama nustatyti patirties marketingo dimensijų poveikį miesto gyventojų ir lankytojų lojalumui. Straipsnio teorinejje dalyje pristatomos patirties bei miesto marketingo sampratos, miesto vartotojai ir jų svarba miestui bei išskiriamos pagrindinès miesto patirties marketingo dimensijos. Atliekant kiekybinị tyrimą, nustatomas patirties marketingo dimensijų poveikis Kauno miesto gyventojų ir lankytojų lojalumui. Naudojant regresinę analizę taip pat nustatytas ryšys tarp Kauno miesto gyventojų ir lankytojų patirties marketingo dimensijų vertinimo ir elgesio bei požiūrio lojalumo.

Raktiniai žodžiai: patirties marketingas, miesto marketingas, lojalumas miestui.

\section{Introduction}

In a constantly growing competitive global market, it has become crucial for cities to create their own unique identity that sets them apart from other cities. According to I. Kazançoğlu and T. Dirsehan (2014) cities need to create their own unique identity and provide memorable experiences in order to create a distinguished image of the city. The uniqueness of the city is created by a wide range of aspects, such as cultural, art, sports events, activities and institutions, recreation areas, architecture and the general environment that combines all the elements. These elements form the city experience and help to shape a positive image of the city, which is necessary to attract and retain the city customers - residents, visitors, businesses, and potential investors.

To ensure a successful marketing strategy for the city, it is crucial to create these experiences for the target customer groups

Kristina ZIKIENE - PhD, associate professor at Marketing Department, Faculty of Economics and Management, Vytautas Magnus University, Lithuania. Address: S. Daukanto str. 28, LT-44248, Kaunas, Lithuania. Phone: +370 37 327856. E-mail: kristina.zikiene@vdu.lt 
of the city who can get involved in them residents and visitors. One of the most important customers of the city are residents who have the greatest potential from all customer groups to attract other residents, visitors, employees, and investors to the city. However, city marketing is customercantered and its perception management, so not only residents but also visitors are seen as important target audiences for the city, influencing the marketing of the city itself (Zenker and Beckmann, 2013). The interaction of residents and visitors who engage with the city, which is willing and able to offer them, creates an "experience economy". The most important element of this economy is the experience itself, which can include museums, theatres, festivals and the city's identity, stories (legends) and the creation of the city's image as a brand. Experience marketing is created by developing these experiences, which include physical and social interactions between city customers and the environment of the city.

Although interest in city marketing has strongly grown, there is still a lack of scientific literature and research on the subject, so most of the conceptual elements and other features in the existing literature have been moved from the concept of brand marketing and applied to city marketing. Experiential marketing in the context of branding is also widely used, but it is still not as common in areas such as city marketing. Customer loyalty to the city is also becoming one of the new paradigms of research, especially considering that it is experience and the expression of its dimensions that in many cases determine the formation of loyalty (both behavioural and attitudinal) to the city. Evaluating experience marketing and its conceptual provisions, theoretical insights of city marketing and the specifics of it in the context of city marketing, the problem of this article is the following: which dimensions of experience marketing affect the loyalty of Kaunas city residents and visitors?

The object of the research: the impact of experience marketing dimensions on the loyalty of Kaunas city residents and visitors.

The aim of the research: to determine the impact of experience marketing dimensions on the loyalty of Kaunas city residents and visitors.

The research methods: literature analysis, questionnaire survey as the quantitative method for empirical research, data analysis.

\section{Experience marketing dimensions in city marketing: theoretical insights}

The concept of experience marketing. One of the pioneers of the experiential marketing concept B. H. Schmitt (1999) defined the concept of experience marketing as marketing which is focused not only on goods and services or its features but also on the experience, rational and affective which is created by the organization. S. Same and J. Larimo (2012) also emphasize the importance of the customer in experience marketing and highlights main aspects of it. According to the authors, experience marketing is strategic customer-oriented marketing that involves an effective cognitive marketing perspective, taking into account the most important aspects of marketing: offer or stimulus, customer-organization interactions, experiences and value creation for customers, 
organizations and society. Experience marketing according to E. Hauser (2007) is "higher" marketing. Organizations have moved away from traditional marketing, which focuses on presenting features and needs of goods and services to creating a valuable experience for customers (Yeh et al., 2019). Until now, the essence of marketing was the customer and his desires. However, the essence of experiential marketing is the interpretation of those desires. According to the author, companies that apply the principle of experience marketing have better chances to have higher market shares than companies that do not apply it. According to A. Williams (2006), experience marketing encourages customers to make a positive decision to buy faster. R. K. Srivastava (2008) emphasizes that valuing the importance of customer involvement encouraged to recognize experience marketing as an effective way to promote brand representation, word-of-mouth communication and loyalty (Smilansky, 2009).
City marketing. Over the last three decades, interest in city marketing has grown significantly (Oguztimur and Akturan, 2016). Although city marketing is increasingly being explored, there is still a lack of a generally accepted concept in the literature to define the concept of it. To solve this problem, J. Piliutyte (2005) systemized the prevailing concepts of city marketing in the existing literature and presented the partial concepts of city marketing shown in Table 1.

By summarizing these different concepts of city marketing (shown in Table 1), it is possible to single out elements that unite them all. First, all these concepts are connected by the main element of the city's marketing - location. Also, city marketing itself is described as a process aiming to meet the needs of city customers and creating a positive image of the city. City marketing can also be seen as the creation of a place that meets the needs of targeted markets (Rauhut, 2016).

\section{Table 1. Partial concepts of city marketing}

\begin{tabular}{|l|l|}
\hline Geo marketing & $\begin{array}{l}\text { Marketing activities that are based on GIS (geographic information systems), the } \\
\text { characteristics of a particular geographical area, and other geographical data for the } \\
\text { planning and implementation of marketing activities. }\end{array}$ \\
\hline Place marketing & Marketing activities aimed to create a positive opinion about a specific place or region. \\
\hline Territorial marketing & $\begin{array}{l}\text { Marketing activities are aimed at widely promoting the competitive and unique } \\
\text { advantages of the area. It is a plan that promotes both tangible and intangible, quantitative } \\
\text { and qualitative, features of the territory to attract external capital and businesses to the } \\
\text { area. }\end{array}$ \\
\hline Regional marketing & $\begin{array}{l}\text { The declining influence of individual regions is leading to their increasing integration } \\
\text { into common structures. These can be regional associations, regional cooperation, } \\
\text { urban networks. }\end{array}$ \\
\hline Urban/city marketing & $\begin{array}{l}\text { This is an overall strategy covering urban development. The main object is the various } \\
\text { groups of people that make up the general "city audience". This audience can be described } \\
\text { by the general interest in the culture of that city. }\end{array}$ \\
\hline
\end{tabular}

Source: J. Piliutytė (2005). 
If a city is considered a product, then it must meet certain expectations and needs of customers. Because the target market of the city is differentiated, so do the needs in each of the target market groups (Melović et al., 2017). S. Zenker and S. Beckmann (2013) distinguish three main target groups of the city - residents, visitors and businesses. E. Braun (2008) adds another group to this division - investors. P. Goovaerts et al. (2014) emphasize that city marketing is a long-term process aimed at attracting precisely these target groups to a specific city. O. Rauhut Kompaniets and D. Rauhut (2016) state that city marketing is considered successful when it meets two main parameters - businesses and city residents' satisfaction with the products and services provided in the city and meeting the expectations of potential target audiences (businesses, visitors and investors). As long as the goods and services that are provided by the city meet these needs, the city's marketing activities are considered successful.

Experience marketing in a city context. Consumer experience is a crucial competitive advantage and commercial success (Yu and Kim, 2020). In the context of place marketing customer experience can help generate a sustainable and unique advantage for any brand or location (Sharma and Nayak, 2019). Place, in this case - city, is the source of affective and cognitive associations, and these associations that create the experience associated with the city (Popescu, 2009). Experience marketing focuses on creating an experience for city customers and this experience can have a positive affective effect, making it important to examine the affective and symbolic connections with the city.
The user experience consists of rational and affective assessment (Brun et al., 2017) which according to K. N. Lemon and P. C. Verhoef (2016) can be extended to other sensory and physical aspects. R. A. Rather (2019) emphasizes that customers develop a strong loyalty (desire to return) to a city if they have a positive experience in that place. P. Sharma and J. K. Nayak (2019) also highlight the importance of a memorable experience for customer behaviour, satisfaction, and evaluation of a place. In tourism, place and city marketing, customer experience is a crucial factor in creating positive behavioural intentions. Therefore, marketing specialists developing city marketing strategies should focus on developing cognitive, affective, and behavioural components (Rather, 2019).

The dimensions of experiential city marketing and its impact on city loyalty. There are a variety of brand experiences' constructions in the scientific literature, that are focused on brand experience, but carried out researchers showed that many of them can be applied to city marketing. In the context of a city, experience and its dimensions are very similar to the brand created experiences and the main difference are the names of those dimensions. Also, it is noted that most dimensions are used only for the study of the tourists (visitors) experience. I. Kazançoğlu and T. Dirsehan (2014) selected dimensions for the experience of city residents and their impact on city loyalty. Six dimensions of city experience adapted to fit both - city residents and visitors (tourists), are as follows:

- Social activities and leisure time experience

- Affective experience 
- Observable experience

- Taste experience

- Disturbing sensory experience

- Nature-related experience

The first dimension involves the evaluation of the city's activities to determine whether that city has the potential for different cultural, art or sports activities and the opportunity for city customers to engage with these activities. The second dimension involves affective associations with the city. The observable experience dimension combines residents' observables of the city, its architecture, and historical sites. The dimension of taste experience includes places related to local food that sets them apart from other places. The essence of the disturbing sensory experience is to analyse reactions to unpleasant visual disturbances, noise pollution and other sensory disturbances that have a negative impact on residents' and visitors' experiences in the city. The nature-related experience dimension of the city is related to nature, green areas of the city that has a visual effect, creating potentially positive emotions.

In the context of the experience marketing dimensions formation and its growing importance for the city, the specifics of the concept of loyalty to the city become apparent. I. Kazançoğlu and T. Dirsehan (2014) emphasize that loyalty to the city can be described as having a sense of pride caused by the city and a psychological attachment to it. In the context of place marketing, loyalty as a concept includes two aspects. The first is behavioural loyalty, which in the context of residents' loyalty means the choice to live in the city for a long time and in the case of visitors to revisit the city. The second is attitudinal loyalty, which involves the recommendations, word-of-mouth communication and is specific to both city customer groups - residents and visitors (McKercher et al., 2012). The effect of the city experience on loyalty can be seen in Figure 1.

As can be seen in Figure 1, the main dimensions of experiential marketing in the city are social activities and leisure time experiences (later in article - social experience), affective, observable, taste, disturbing sensory and nature-related experiences. All experience dimensions separately and the general experience in the city affect attitudinal and behavioural loyalty to the city. Therefore, the creation and improvement of positive experiences in the city are important to increase consumer loyalty to the city.

\section{Methodology of the research}

To determine the impact of the experiential marketing dimensions on the loyalty of the city for city residents and visitors, one of the quantitative researches - a questionnaire survey was chosen. The survey method chosen for the research was an online survey. The questionnaire was prepared on the basis of the dimensions of the city experience distinguished in the study by I. Kazançoğlu and T. Dirsehan (2014), applying them to the customers and market environment of Kaunas city. In the questionnaire, the respondents had to evaluate the dimensions of experience marketing in the city - social experience, affective experience, observable experience, taste experience, disturbing sensory experience and nature-related experience. Each of the experiences' dimension was evaluated by the number 


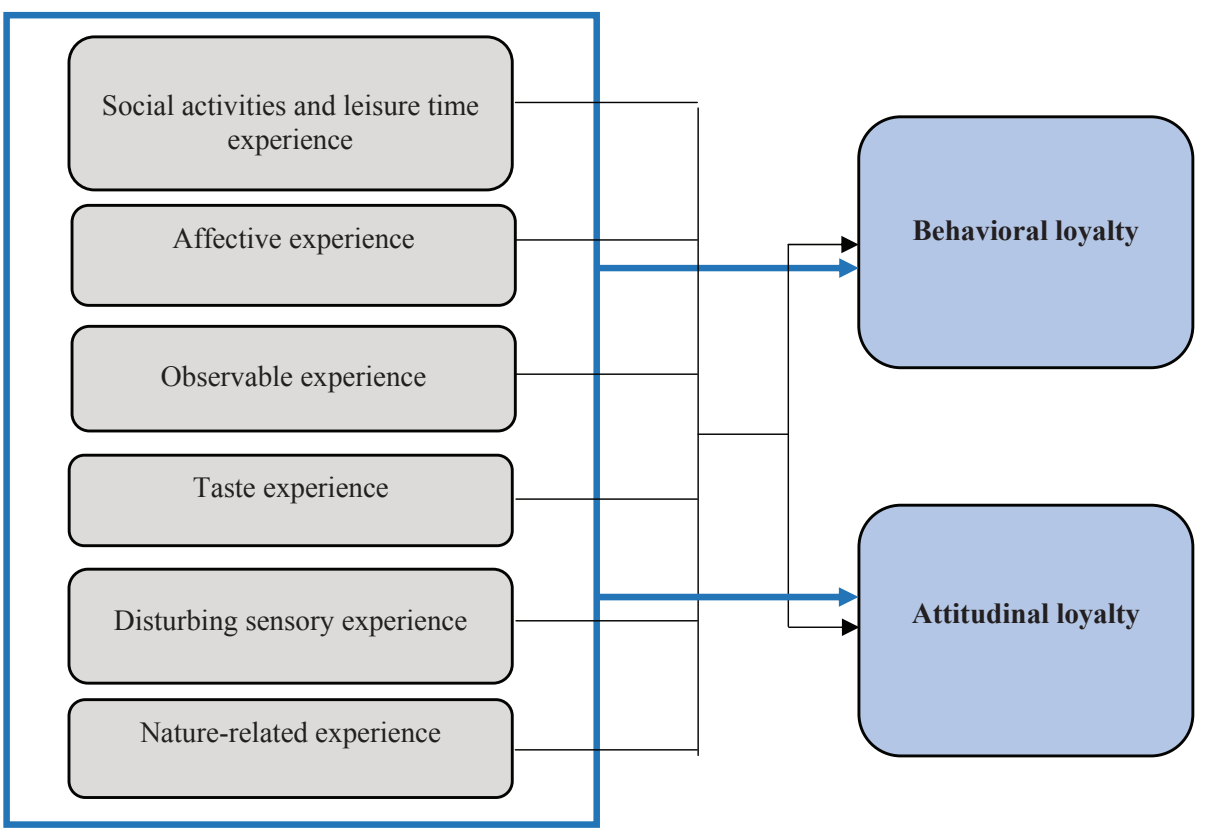

general experience in the city

Fig. 1. The impact of the city residents' and visitors' experience dimensions on a city

Source: İ. Kazançoğlu and T. Dirsehan (2014).

of statements that best reveal it, given on the five-point Likert scale (where 1 - completely disagree with the given statement, and 5 - completely agree). Customer loyalty to the city was assessed on the basis of behavioural and attitudinal measures, also using the five-point Likert scale. Two target groups were selected - Kaunas city residents and city visitors. These research groups were selected to compare how the same experiential marketing dimensions affect different groups of city customers and how the same experiences in the city can differently shape the loyalty of these groups. Two separate questionnaires were prepared, one for the city residents and the other one translated into English and presented for city visitors. On the basis of evaluations reported by the respondents, regression analysis (one variable value prediction by other variable values) was made in order to find out the dimensions of experience marketing that affect the loyalty of city residents and visitors.

Taking into account the number of Kaunas city population and the number of tourists who visited Kaunas city in 2019, a representative sample of quantitative research was calculated with the help of statistical methods. The study was expected to give a $95 \%$ confidence level, with a sampling error of 5\%. After performing the calculations, it was decided to interview 384 respondents, dividing them by half - 192 Kaunas city residents and 192 Kaunas city visitors. 
Prior to data analysis, the reliability of the questionnaire was checked by calculating Cronbach's alpha coefficients. The closer the value of the Cronbach's alpha coefficient to each of the dimensions studied is 1 , the higher the reliability of the questionnaire. The values of the coefficients of all dimensions of this study range from 0.911 to 0.972 , so the values are close to 1 , so the reliability of the questionnaire is suitable for further analysis of the collected data.

\section{Research results}

As already mentioned, city loyalty is affected by six dimensions of experience marketing - social, affective, observable, taste, disturbing sensory, and nature-related experiences. Using linear regression analysis, the aim was to find out the effect of independent variables (experience marketing dimensions) on city loyalty. First, it was determined whether the dependent variable (behavioral and attitudinal loyalty components) correlated with the regressors. The obtained results are presented in Table 2. The dependent variable correlates with the independent variable when $p<0.05$. As can be seen, the linear relationship between all dependent variables and regressors is statistically significant because $\mathrm{p}<0.05$ of all regressors.

Loyalty assessment of Kaunas city visitors. Analysing the behavioural loyalty of Kaunas city visitors, the coefficient of determination ( $\mathrm{R}$ square) was first calculated, which shows the reliability of the linear regression model for the data. The value of the coefficient of determination $\left(\mathrm{R}^{2}\right)=0.355$. It means that regressors explain 35.5 percent dependent variable (behavioural loyalty) behaviour. It is also important to find out what effect each individual regressor has on the dependent

Table 2. $\mathbf{P}$ values of regressors

\begin{tabular}{|c|l|c|c|c|c|c|c|}
\hline \multicolumn{2}{|c|}{} & $\begin{array}{c}\text { Social } \\
\text { experience }\end{array}$ & $\begin{array}{c}\text { Affective } \\
\text { experience }\end{array}$ & $\begin{array}{c}\text { Observable } \\
\text { experience }\end{array}$ & $\begin{array}{c}\text { Taste } \\
\text { experience }\end{array}$ & $\begin{array}{c}\text { Disturbing } \\
\text { sensory } \\
\text { experience }\end{array}$ & $\begin{array}{c}\text { Nature- } \\
\text { related } \\
\text { experience }\end{array}$ \\
\hline $\begin{array}{l}\text { Plans to live in } \\
\text { Kaunas city for } \\
\text { next 5 years } \\
\text { (for city } \\
\text { residents) }\end{array}$ & 0,000 & 0,000 & 0,000 & 0,000 & 0,000 & 0,000 \\
\cline { 2 - 7 } & $\begin{array}{l}\text { Plans to visit } \\
\text { Kaunas city in the } \\
\text { future } \\
\text { (for city visitors) }\end{array}$ & 0,000 & 0,000 & 0,000 & 0,000 & 0,002 & 0,002 \\
\hline \multirow{2}{*}{$\begin{array}{l}\text { Recommenda- } \\
\text { tions to live in } \\
\text { Kaunas city }\end{array}$} & 0,000 & 0,000 & 0,000 & 0,000 & 0,000 & 0,000 \\
\hline
\end{tabular}


Table 3. Beta coefficients of the modified model of behavioural loyalty for city visitors

\begin{tabular}{|c|c|c|c|c|c|}
\hline \multirow[t]{2}{*}{ Model } & \multicolumn{2}{|c|}{ Unstandardized coefficients } & \multirow{2}{*}{$\begin{array}{c}\begin{array}{c}\text { Standardized } \\
\text { Coefficients }\end{array} \\
\text { Beta }\end{array}$} & \multirow[t]{2}{*}{$\mathbf{t}$} & \multirow[t]{2}{*}{ Sig. } \\
\hline & B & Std. Error & & & \\
\hline &, 026 & ,404 & & 065 & ,948 \\
\hline Social experience & 438 & , 139 & 314 & 3,151 & ,002 \\
\hline Affective experience &,- 545 & , 148 &,- 424 & $-3,668$ &, 000 \\
\hline General experience & 1,016 &, 132 & ,668 & 7,712 & ,000 \\
\hline
\end{tabular}

variable (behavioural loyalty). Calculated regression coefficients revealed that social, affective and general experience in the city has a direct positive effect on behavioural loyalty to the city for visitors. Meanwhile, observable, taste, disturbing sensory and nature-related experiences do not have a statistically significant effect on the loyalty of city visitors, so they are excluded from the model of further research. After removing these regressors, the obtained coefficient of determination was $\left(R^{2}\right)=0.352$. As the coefficient decreased slightly, it can be stated that the influence of the removed regressors on the study model was not significant. After removing regressors that do not affect behavioural loyalty, it is important to find out whether each remaining regressor has a significant effect on the dependent variable (behavioural loyalty). It can be seen in Table 3.

As can be seen in Table 3, all the remaining regressors - the dimensions of social experience and affective experience as well as the general experience - have a direct impact on the assessment of behavioural loyalty for city visitors.

Analysing the loyalty of Kaunas city visitors' attitudinal loyalty, the coefficient of determination was calculated, which is equal to $\left(R^{2}\right)=0.69$. It can be said that the regressors explain 69 percent of dependent variable (attitudinal loyalty) behaviour. To find out what influence each regressor has on the dependent variable (attitudinal loyalty), the calculated coefficients revealed that the affective and observable dimensions of the experience and the general experience have a direct positive effect on the attitudinal loyalty for city visitors. Meanwhile, the social, taste, disturbing sensory and nature-related experience dimensions do not have a statistically significant effect, so they are excluded from the further research model. After removing these regressors, the obtained coefficient of determination was $\left(R^{2}\right)=0.689$. Since the coefficient decreased slightly, it can be said that the influence of the removed regressors on the study model was not significant. After removing regressors that do not affect attitudinal loyalty, it is important to find out whether each remaining regressor has a significant effect on the dependent variable (attitudinal loyalty). It can be seen in Table 4.

As can be seen in Table 4, all remaining regressors - the affective and observable dimensions of experience marketing, as well as the general experience in 
Table 4. Beta coefficients of the modified model of attitudinal loyalty for city visitors

\begin{tabular}{|l|c|c|c|c|c|}
\hline \multirow{2}{*}{ Model } & \multicolumn{2}{|c|}{ Unstandardized coefficients } & $\begin{array}{c}\text { Standardized } \\
\text { Coefficients }\end{array}$ & \multirow{2}{*}{ t } & \multirow{2}{*}{ Sig. } \\
\cline { 2 - 4 } & B & Std. Error & Beta & & \\
\hline &,- 886 &, 251 & & $-3,537$ &, 001 \\
\hline Affective experience &, 524 &, 090 &, 446 & 5,837 &, 000 \\
\hline Observable experience &, 283 &, 074 &, 240 & 3,806 &, 000 \\
\hline General experience &, 319 &, 083 &, 229 & 3,822 &, 000 \\
\hline Dependent variable: Attitudinal loyalty
\end{tabular}

the city - have a direct impact on the assessment of behavioural loyalty of city visitors, so these regressors are left in the study model.

Based on the results of this study, the theoretical research model (Figure 1) specified at the beginning of this work was adjusted. A modified research model explaining the impact of Kaunas city visitors' experience dimensions on city loyalty is presented in Figure 2.

Loyalty assessment of Kaunas city residents. Analysing the behavioural loyalty of Kaunas city residents, the coefficient of determination was calculated, which was equal to $\left(\mathrm{R}^{2}\right)=0.395$. It can be said that the regressors explain 39.5 percent of the dependent variable (behavioural loyalty) behaviour. It is also important to find out what effect each individual regressor has on the dependent variable (behavioural loyalty). The calculated regression coefficients revealed that the affective experience dimension and the nature-related dimension, as well as the overall experience in the city, have a direct positive effect on the behavioural loyalty of the city visitors. Meanwhile, the remaining regressors (social experience, observable experience, taste experience, and disturbing sensory experience) have no statistically significant effect on

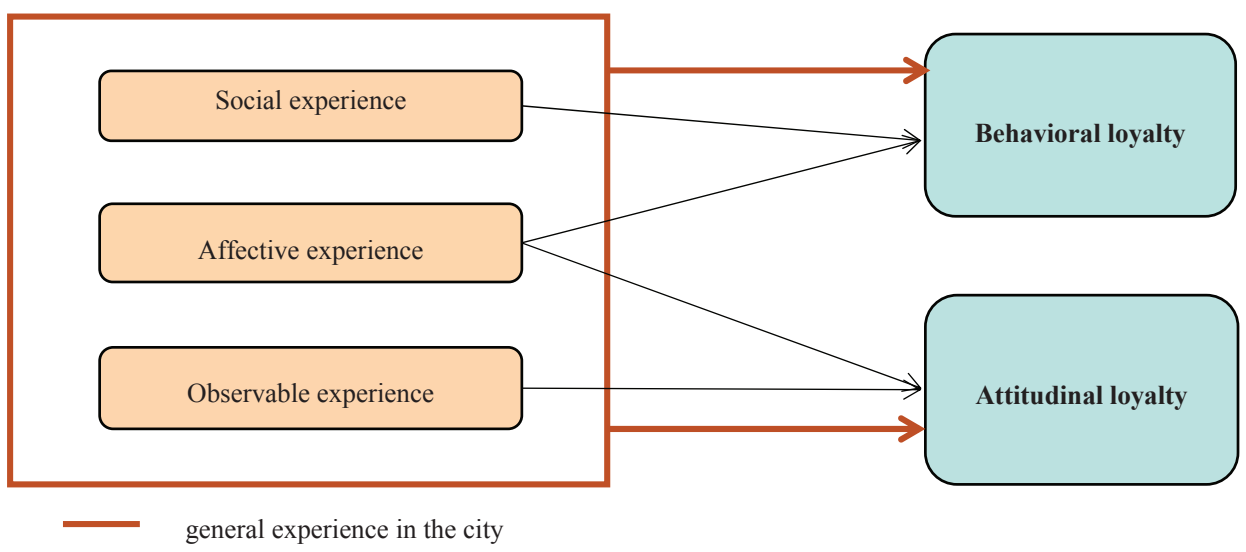

Fig. 2. The modified model of experience marketing dimensions effect on the city residents' loyalty 
Table 5. Beta coefficients of the modified model of behavioural loyalty for city residents

\begin{tabular}{|l|c|c|c|c|c|}
\hline \multirow{2}{*}{ Model } & \multicolumn{2}{|c|}{ Unstandardized coefficients } & $\begin{array}{c}\text { Standardized } \\
\text { Coefficients }\end{array}$ & \multirow{2}{*}{ t } & Sig. \\
\cline { 2 - 4 } & B & Std. Error & Beta & & \\
\hline &,- 406 &, 472 & &,- 860 &, 391 \\
\hline Affective experience &, 374 &, 141 &, 245 & 2,655 &, 009 \\
\hline $\begin{array}{l}\text { Nature-related } \\
\text { experience }\end{array}$ &, 164 &, 132 &, 095 & 2,249 &, 013 \\
\hline General experience &, 492 &, 118 &, 351 & 4,191 &, 000 \\
\hline Dependent variable: Behavioural loyalty
\end{tabular}

behavioural loyalty and are excluded from the further study model. After removing these regressors, the obtained coefficient of determination was $\left(\mathrm{R}^{2}\right)=0.386$. As the coefficient decreased slightly, it can be stated that the influence of the removed regressors on the study model was not significant. After removing regressors that do not affect behavioural loyalty, it is important to find out whether each remaining regressor has a significant effect on the dependent variable (behavioural loyalty). It can be seen in Table 5 .

As can be seen in Table 5, the remaining regressors have a direct influence on the assessment of behavioural loyalty of city residents.

Analysing the attitudinal loyalty of Kaunas city residents, the coefficient of determination was calculated, which was equal to $\left(\mathrm{R}^{2}\right)=0.464$. It can be said that the regressors explain 46.4 percent of the dependent variable (attitudinal loyalty) behaviour. Calculated regression coefficients revealed that the affective, observable, disturbing sensory experience dimension, as well as the general experience in the city, have a direct positive impact on the attitudinal loyalty of city residents. Meanwhile, social, taste and

Table 6. Beta coefficients of the modified model of attitudinal loyalty for city residents

\begin{tabular}{|l|c|c|c|c|c|}
\hline \multirow{2}{*}{ Model } & \multicolumn{2}{|c|}{ Unstandardized coefficients } & $\begin{array}{c}\text { Standardized } \\
\text { Coefficients }\end{array}$ & \multirow{2}{*}{ t } & \multirow{2}{*}{ Sig. } \\
\cline { 2 - 4 } & $\mathbf{B}$ & Std. Error & Beta & & \\
\hline &, 457 &, 330 & & 1,387 &, 167 \\
\hline Affective experience &, 256 &, 111 &, 218 & 2,310 &, 022 \\
\hline Observable experience &, 253 &, 099 &, 201 & 2,552 &, 011 \\
\hline $\begin{array}{l}\text { Disturbing sensory } \\
\text { experience }\end{array}$ &, 163 &, 067 &, 168 & 2,421 &, 016 \\
\hline General experience &, 226 &, 086 &, 210 & 2,633 &, 009 \\
\hline Dependent variable: Attitudinal loyalty
\end{tabular}




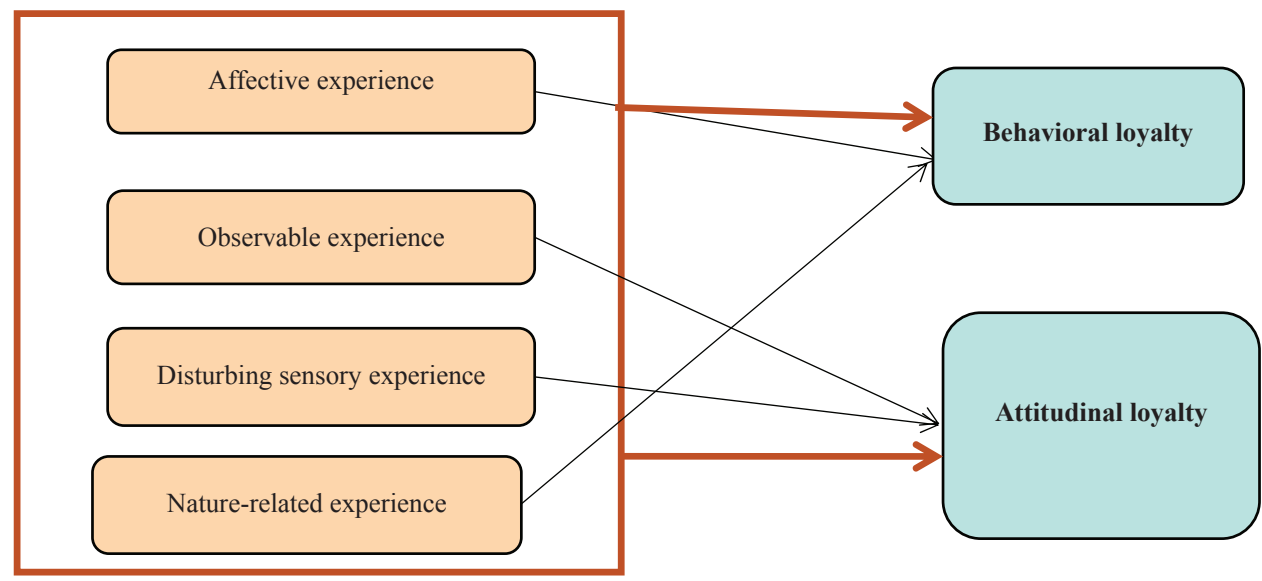

Fig. 3. The modified model of the experience marketing dimensions' effect on the city residents' loyalty

nature-related experiences do not have a statistically significant effect on attitudinal loyalty, so they are excluded from the model of further research. After removing these regressors, the obtained coefficient of determination was $\left(\mathrm{R}^{2}\right)=0.457$. As the coefficient decreased slightly, it can be stated that the influence of the removed regressors on the study model was not significant. After removing regressors that do not affect attitudinal loyalty, it is important to find out whether each remaining regressor has a significant effect on the dependent variable (attitudinal loyalty). It can be seen in Table 6 .

As can be seen in Table 6, all remaining regressors have a direct influence on the assessment of attitudinal loyalty for city residents. These regressors are left in the study model.

Based on the results of this study, the theoretical research model (Figure 1) specified at the beginning of this work was adjusted. A modified research model explaining the impact of Kaunas city residents' experience dimensions on city loyalty is presented in Figure 3.

\section{Conclusions}

To describe the impact of the city experience marketing on city consumers, six main dimensions of experience marketing were distinguished. Those are social, affective, observable, taste, disturbing sensory, and nature-related experiences.

Loyalty to the city can be described as a sense of pride caused by the city and the psychological attachment to it. City loyalty involves two aspects. The first is behavioural loyalty, which in the context of residents' loyalty means the choice to live in the city for a long time, and in the case of city visitors, a repeated visit to the city. The second is attitudinal loyalty, which includes recommendations, word-of-mouth communication and is common to both city residents and visitors. Six dimensions of experience marketing in the city have 
an impact on both - attitudinal and behavioural loyalty to the city. Therefore, the creation and improvement of positive experiences in the city are important to increase consumer loyalty to the city.

Regression analysis revealed that out of the six dimensions of experience marketing, three of them - social, affective and observable - affect the loyalty of city visitors. Behavioural loyalty of city visitors is influenced by the dimensions of social experience, affective experience and general experience in the city. Meanwhile, attitudinal loyalty of city visitors is influenced by the affective, observable experience dimensions and the general experience in the city.

The results of regression analysis showed that the loyalty of Kaunas city residents is influenced by four dimensions of experience - affective, observable, disturbing sensory and nature-related. The behavioural loyalty is influenced by the dimensions of affective experience, nature-related experience and general experience in the city, and attitudinal loyalty is influenced by the dimensions of affective experience, observable experience, disturbing sensory experience and general experience in the city.

Summarizing the results of this research, it can be stated that different customers of the city are characterized by different assessments of the same dimensions of marketing and expression of loyalty. Therefore, it is crucial to apply different measures to improve the experience of city residents and visitors in the city and increase their loyalty.

\section{References}

1. Braun, E. (2008). City Marketing: Towards an Integrated Approach. - Erasmus Research institute of Management. Rotterdam: Erasmus School of Economics.

2. Brun, I., Rajaobelina, L., Ricard, L., Berthiaume, B. (2017). Impact of Customer Experience on Loyalty: A Multichannel Examination // The Service Industries Journal. Vol. 37(5-6), pp. 317340. doi: 10.1080/02642069.2017.1322959.

3. Goovaerts, P., van Biesbroeck H., van Tilt, T. (2014). Measuring the Effect and Efficiency of City Marketing // Procedia Economics and Finance. Vol. 12, pp. 191-198. doi: 10.1016/ s2212- 5671(14)00335-9.

4. Hauser, E. (2007). Brandweek: Experiential Marketing, in Experiential Marketing Forum. 26 July 2007. Internet access: < http://ixma. org/articles/brandweek072607.pdf>, [accessed March 15, 2020].

5. Kazançoğlu, İ., Dirsehan, T. (2014). Exploring Brand Experience Dimensions for Cities and Investigating their Effects on Loyalty to a City // Business \& Economics Research Journal.
Vol. 5, pp. 17-37. Internet access: <https:// www.researchgate.net/publication/272498236_ Exploring_Brand_Experience_Dimensions_ for_Cities_and_Investigating_Their_Effects_ on_Loyalty_to_a_City>, [accessed May 16, 2020].

6. Lemon, K. N., Verhoef, P. C. (2016). Understanding Customer Experience throughout the Customer Journey // Journal of Marketing. Vol. 80(6), pp. 69-96. doi: 10.1509/ jm.15.0420.

7. McKercher, B., Denizci-Guillet, B., Ng, E. (2012). Rethinking Loyalty // Annals of Tourism Research. Vol. 39, pp. 708-734. doi: 10.1016/j. annals.2011.08.005.

8. Melović, B., Mitrović, S., Đokaj, A. (2017). City-brand Building - from city marketing to City Branding // Proceedings of the Faculty of Economics in East Sarajevo. Vol. 14, pp. 51-59. doi: 10.7251/ZREFIS.

9. Oguztimur, S., Akturan, U. (2016). Synthesis of City Branding Literature (1988-2014) as a Research Domain // International Journal of 
Tourism Research. Vol. 18(4), pp. 357-372. doi: $10.1002 /$ jtr.2054.

10. Piliutyte, J. (2005). Rinkodaros metodų taikymo teoriniai aspektai miestų plètros kontekste. Viešoji politika ir administravimas. Vol. 11, pp. 95-101. Internet access: <https://www. mruni.eu/upload/iblock/2bc/10_j.piliutyte. pdf>, [accessed March 26, 2020].

11. Popescu, R. I. (2009). The Branding Potential of Bucharest. Strategy and Success Factors // Theoretical and Empirical Researches in Urban Management. Vol. 4(13), pp. 9-27. Internet access: <https://www.jstor.org/ stable/24872626?seq=1\#metadata_info_tab_ contents $>$, [accessed March 28, 2020].

12. Rather, R. A. (2019). Customer Experience and Engagement in Tourism Destinations: The Experiential Marketing Perspective // International Journal of Tourism Research. Vol. 37(1), pp. 15-32. doi: 10.1080/10548408.2019.1686101.

13. Rauhut Kompaniets, O., Rauhut, D. (2016). Why Urban and Rural Place Marketing Strategies Differ: A Theoretical Discussion // Romanian Journal of Regional Science. Vol. 10, pp. 23-40. Internet access: <https://www.researchgate. net/publication/304039733_WHY_URBAN AND_RURAL_PLACE__MARKETING_ STRATEGIES_DIFFER_A_THEORETICAL_ DISCUSSION>, [accessed March 25, 2020].

14. Same, S., Larimo, J. (2012). Marketing Theory: Experience Marketing and Experiential Marketing. 7th International Scientific Conference Business and Management 2012, May 10-11, 2012, Vilnius, Lithuania.

15. Schmitt, B. H. (1999). Experiential Marketing // Journal of Marketing Management. Vol. 15, pp. 53-67. doi: 10.1362/026725799784870496.

16. Sharma, P., Nayak, J. K. (2019). Understanding Memorable Tourism Experiences as the
Determinants of Tourists // International Journal of Tourism Research, Vol. 21(4), pp. 504-518. doi: 10.1002/jtr.2278.

17. Smilansky, S. (2009). Experiential Marketing. A Practical Guide to Interactive Brand Experiences. - London: Kogan Page.

18. Srivastava, R. K. (2008). How Experiential Marketing Can be Used to Build Brands - a Case Study of Two Specialty Stores // Innovative Marketing. Vol. 4(2). Internet access: <https:// www.academia.edu/18556825/Experiential_ Marketing_Indian_Paper_>, [accessed March $25,2020]$.

19. Williams, A. (2006). Tourism and Hospitality Marketing: Fantasy, Feeling and Fun // International Journal of Contemporary Hospitality Management. Vol. 18(6), pp. 482495. doi: 10.1108/09596110610681520.

20. Yeh, T. M., Chen, S. H., Chen, T. F. (2019). The Relationships among Experiential Marketing, Service Innovation, and Customer Satisfaction. A Case Study of Tourism Factories in Taiwan // Sustainability 2019. Vol. 11, p. 1041.

21. Yu, E., Kim, J. (2020). The Relationship between Self-City Brand Connection, City Brand Experience, and City Brand Ambassadors // Sustainability. Vol. 12, p. 982. doi: 10.3390/ su12030982.

22. Zenker, S., Beckmann, S. (2013). My Place is not your Place-Different Place Brand Knowledge by Different Target Groups // Journal of Place Management and Development. Vol. 6, pp. 6-17. doi: 10.1108/17538331311306078.

The paper submitted: August 10, 2020

Prepared for publication: December 10, 2020 


\section{Kristina ZIKIENE், Laura GAGIŠKYTÉ \\ PATIRTIES MARKETINGO DIMENSIJŲ POVEIKIO ĮTAKA MIESTO LANKYTOJŲ IR GYVENTOJŲ LOJALUMUI}

\section{S a n t r a u k a}

Vis didejjančioje globalioje konkurencinèje rinkoje miestams itin svarbu kurti savo unikalų identitetą, kuris skirtų juos nuo kitų miestų. Miestų originalaus identiteto bei įsimintinų patirčių kūrimas taip pat būtinas tam, kad kurtų unikalų miesto įvaizdị. Miesto išskirtinumas sukuriamas plataus spektro aspektų - kultūrinių, meno, sporto renginių, veiklų bei institucijų, poilsio vietų, architektūros bei visa tai kuriančios bendrosios aplinkos. Šie elementai sukuria miesto patirtị ir padeda formuoti teigiamą jo ịvaizdį, reikalingą pritraukti ir išlaikyti miesto vartotojus - gyventojus, lankytojus, įmones bei potencialius investuotojus.

Norint užtikrinti sèkmingą miesto marketingo strategiją, itin svarbu kurti šias patirtis tikslinems miesto vartotojų grupems, galinčioms ịsitraukti $\mathfrak{i}$ jas, - gyventojams bei lankytojams. Vieni iš svarbiausių miesto vartotojų - gyventojai, kurie turi didžiausią potencialą iš visų vartotojų grupių pritraukti $\mathfrak{i}$ miestą kitus gyventojus, lankytojus, darbuotojus bei investuotojus. Visgi miesto marketingas orientuotas ị vartotoją ir jo suvokimo valdymą, todel ne tik gyventojai, bet ir miesto lankytojai laikomi svarbiomis tikslinèmis miesto auditorijomis, darančiomis poveiki pačiam miesto marketingui. Gyventojų bei lankytojų, įsitraukiančių ỉ miesto patirtis, sąveika su miestu, norinčiu ir gebančiu jas pasiūlyti, sukuria "patirties ekonomiką“. Svarbiausias šios ekonomikos elementas yra pačios patirtys, galinčios apimti muziejus, teatrus, festivalius bei miesto identitetą, istorijas (legendas) ir miesto, kaip prekès ženklo, ịvaizdžio kūrimą. Taigi, patirties marketingas yra sukuriamas vystant šias patirtis, apimančias fizines bei socialines interakcijas tarp miesto vartotojų ir miesto aplinkos. Patirties marketingo ir jo dimensijų raiška miestų marketingo kontekste daugeliu atvejų lemia miesto vartotojų gyventojų ir turistų - lojalumo (tiek elgsenos, tiek požiūrio) miestui formavimąsi, kas tampa vienu iš svarbiausių miestų marketingo tikslų.
Straipsnyje analizuojamas patirties marketingo dimensijų poveikis Kauno miesto gyventojų ir lankytojų lojalumui. Atlikus patirties marketingo sampratos, miestų marketingo, patirties marketingo miesto kontekste ir miesto patyrimo marketingo dimensijų ir jų poveikio miesto lojalumui teorinę analizę, parengiama ir pagrindžiama empirinio tyrimo metodologija bei pateikiami atlikto kiekybinio tyrimo rezultatai. Empirinio tyrimo metu gautiems duomenims ịvertinti naudota regresinè analizè (vieno kintamojo reikšmių prognozavimas pagal kito kintamojo reikšmes).

Tyrimas atkleidè, kad skirtingų miesto auditorijų lojalumui poveikị daro skirtingos patirties marketingo dimensijos. Atlikus regresinę analizę, paaiškèjo, jog iš šešių patirties marketingo dimensijų (socialinès, emocinès, stebėjimo, skonio, trikdančios jutiminés ir su gamta susijusios patirties), trys iš jų - socialinè, emocinè bei stebejjimo - daro ịtaką miesto lankytojų lojalumui. Jų elgesio lojalumui įtaką daro socialinès patirties, emocinès patirties dimensijos bei bendroji patirtis mieste. Miesto lankytojų požiūrio lojalumui ịtaką daro emocinès, stebéjimo patirties dimensijos bei bendroji patirtis mieste.

Regresinès analizès rezultatai taip pat parodé, jog Kauno miesto gyventojų lojalumui ịtaką daro keturios patirties dimensijos - emocinè, stebèjimo, trikdanti jutiminè bei susijusi su gamta. Miesto gyventojų elgesio lojalumui itaką daro emocinès patirties ir su gamta susijusios patirties dimensijos bei bendroji patirtis mieste, o požiūrio lojalumui emocinès patirties, stebejimo patirties ir trikdančios jutiminès patirties dimensijos bei bendroji patirtis mieste.

Apibendrinus tyrimo rezultatus galima teigti, kad skirtingiems miesto vartotojams būdingas skirtingas tų pačių patirties marketingo dimensijų vertinimas bei lojalumo raiška. Taigi, daroma išvada, kad miestų marketingo kontekste itin svarbu taikyti skirtingas priemones miesto gyventojų ir lankytojų patirtims mieste gerinti bei jų lojalumui formuoti. 